\title{
Functional Organization of Rat Olfactory Bulb Glomeruli Revealed by Optical Imaging
}

\author{
Asaf Keller, ${ }^{1}$ Sergey Yagodin, ${ }^{1}$ Vassiliki Aroniadou-Anderjaska, ${ }^{1}$ Lee A. Zimmer, ${ }^{1}$ Matthew Ennis, ${ }^{1}$ \\ Norman F. Sheppard $\mathrm{Jr}^{2}$ and Michael T. Shipley ${ }^{1}$ \\ ${ }^{1}$ Department of Anatomy and Neurobiology and the Program in Neuroscience, University of Maryland School of \\ Medicine, Baltimore, Maryland 21201, and 2Department of Biomedical Engineering, Johns Hopkins University, \\ Baltimore, Maryland 21218
}

The functional organization and synaptic physiology of olfactory bulb glomeruli were studied in rat in vitro slice preparations stained with the voltage-sensitive dye $\mathrm{RH}-155$. Optical signals were recorded with a 100-element photodiode array at high temporal resolution. Pharmacological and ionic manipulations were used to investigate synaptic responses to stimulation of the olfactory nerve layer (ONL). ONL stimulation evoked a sodium-mediated compound action potential that propagated across the ONL and invaded individual glomeruli. This presynaptic volley evoked calcium-dependent synaptic responses the amplitudes of which were largest within the glomerular layer (GL); smaller amplitude responses were recorded in deeper layers of the olfactory bulb. Synaptic responses in the GL were attenuated by the non-NMDA ionotropic glutamate receptor antagonist CNQX; the residual component was suppressed by the NMDA glutamate receptor antagonist AP-5. The GABA

The main olfactory bulb is a well-characterized structure. Most previous functional studies have focused on the interactions between mitral and tufted cells and granule cells (for review, see Macrides and Davis, 1983; Shepherd, 1991; Nickell and Shipley, 1992; Shipley and Ennis, 1996). In the rat, olfactory nerve (ON) axons form glutamatergic synapses with the apical dendrites of mitral and tufted cells (Ennis et al., 1996; Aroniadou-Anderjaska et al., 1997b; Kosaka et al., 1997). The responses of mitral cells to ON inputs are regulated by GABAergic granule cells, via reciprocal dendrodendritic interactions (Price and Powell, 1970; Nicoll, 1971).

By contrast, much less is known about the functional organization and synaptic physiology of the glomerular layer (GL) of the olfactory bulb. This is attributable, in large part, to the relatively small size of most neurons in this layer that renders electrophysiological investigations particularly difficult. Anatomical studies demonstrate that both ON axons and the dendrites of mitral and tufted cells synapse with juxtaglomerular neurons, which include GABAergic periglomerular cells and other inter-

\footnotetext{
Received Sept. 8, 1997; revised Dec. 4, 1997; accepted Jan. 21, 1998.

This work was supported in part by Public Health Service Grants NS-31078 and NS-35360 to A.K., DC-02588 and DC-00347 to M.T.S., and DC-03195 to M.E. We thank Kelly Ciombor for expert assistance. We are also grateful for critical comments and discussion provided by Drs. B. E. Alger, L. B. Cohen, J. S. Kauer, and B. M. Salzberg.

The first two authors contributed equally to this work.

Correspondence should be addressed to Dr. Asaf Keller, Department of Anatomy and Neurobiology, University of Maryland School of Medicine, 685 West Baltimore Street, Baltimore, MD 21201.

Copyright (C) 1998 Society for Neuroscience $\quad 0270-6474 / 98 / 182602-11 \$ 05.00 / 0$
}

receptor antagonist bicuculline methiodide had little effect, whereas the $\mathrm{GABA}_{\mathrm{B}}$ receptor agonist baclofen dramatically attenuated ONL-evoked synaptic responses. The effects of baclofen were reversed by the $\mathrm{GABA}_{\mathrm{B}}$ receptor antagonist CGP35348. Paired-pulse depression of ONL-evoked synaptic responses in the GL was partially reversed by CGP35348. These findings suggest that olfactory nerve axons release glutamate to activate both NMDA and non-NMDA receptors on GL neurons, that $\mathrm{GABA}_{\mathrm{A}}$ receptor-mediated inhibition has little effect on these responses, and that $\mathrm{GABA}_{\mathrm{B}}$ receptor-mediated inhibition may act presynaptically on olfactory nerve axons to modulate their inputs to olfactory bulb neurons.

Key words: olfactory glomeruli; glutamate; NMDA; GABA; presynaptic inhibition; paired-pulse depression; CGP35348; $\mathrm{RH}-155$ neurons (Reese and Brightman, 1970; Pinching and Powell, 1971; White, 1972; Kosaka et al., 1997). The dendrites of periglomerular cells are thought to form inhibitory, GABAergic synapses with the dendrites of mitral and tufted cells. Although receptor binding studies suggest that both $\mathrm{GABA}_{\mathrm{A}}$ and $\mathrm{GABA}_{\mathrm{B}}$ receptors are localized in the GL, the cellular localization and physiological effects of these receptors have not been determined.

It is difficult, using conventional electrophysiological techniques, to distinguish between intraglomerular inhibition (mediated by periglomerular cells) and infraglomerular inhibition (mediated by granule cells). This distinction is important because the two classes of inhibitory neurons are involved in different functional circuits that may have different roles in olfactory information processing (Nickell et al., 1994; Shipley et al., 1996). Intraglomerular inhibition by periglomerular cells may be involved primarily in modulating ON inputs, possibly via presynaptic inhibition (Freeman, 1974a; Nickell et al., 1994). Infraglomerular inhibition by granule cells may also modulate ON inputs (see Yokoi et al., 1995) and is also involved in the regulation of centrifugal feedback inputs to the olfactory bulb, which synapse primarily with granule cells (see Nickell et al., 1994; Shipley and Ennis, 1996).

The recent development of the mammalian olfactory bulb slice preparation (Nickell et al., 1994; Ennis et al., 1996; AroniadouAnderjaska et al., 1997b) has allowed us to address some of these issues with electrophysiological techniques (Heyward et al., 1996; Aroniadou-Anderjaska et al., 1997b). In the present study, we took advantage of a functional-imaging approach (see Orbach 
and Cohen, 1983; Cinelli and Salzberg, 1987; Kauer et al., 1987) to further investigate the synaptic physiology of olfactory glomeruli. In this approach, in vitro slices of rat olfactory bulb are stained with a voltage-sensitive dye that reports changes in membrane potential as changes in light absorbence. These optical signals allow us to monitor the activity of multiple neuronal elements simultaneously at high temporal resolution and to investigate mechanisms underlying their synaptic interactions.

Parts of this paper have been published previously in abstract form (Yagodin et al., 1996).

\section{MATERIALS AND METHODS}

Preparation. Young adult (4-6 weeks old; 80-250 gm) male Sprague Dawley rats were used in this study. Rats were anesthetized with chloral hydrate $(35 \mathrm{mg} / \mathrm{kg}$, i.p.), and $400 \mu \mathrm{m}$ horizontal slices from the olfactory bulb were prepared as described previously (Nickell et al., 1994, 1996; Ennis et al., 1996; Aroniadou-Anderjaska et al., 1997b). The slices were placed in an interface-type recording chamber, maintained at room temperature, and aerated with a humidified gas mixture of $95 \% \mathrm{O}_{2}$ and $5 \% \mathrm{CO}_{2}$. They were continuously perfused at $0.7 \mathrm{ml} / \mathrm{min}$ with artificial CSF (ACSF) composed of (in mM): $\mathrm{NaCl} 124, \mathrm{NaHCO}_{3} 26, \mathrm{NaH}_{2} \mathrm{PO}_{4}$ $1.2, \mathrm{KCl} 3.2, \mathrm{MgSO}_{4} 1.2, \mathrm{CaCl}_{2} 2.4$, and glucose 10 ; the ACSF solution was saturated with $95 \% \mathrm{O}_{2}$ and $5 \% \mathrm{CO}_{2}$. At least $1 \mathrm{hr}$ after the slices were harvested, they were stained with the potential-sensitive dye RH155 (100 $\mu \mathrm{M}$; Molecular Probes, Eugene, OR). The dye was dissolved in ACSF, and a single slice was placed in a static bath containing this solution and continuously saturated with $95 \% \mathrm{O}_{2}$ and $5 \% \mathrm{CO}_{2}$ for $30-60$ $\min$. The stained slice was then transferred to an immersion-type recording chamber and continuously perfused at $2 \mathrm{ml} / \mathrm{min}$ with ACSF at $22-24^{\circ} \mathrm{C}$.

To test whether the staining procedure affected the viability of the slices, we obtained electrophysiological recordings in some experiments before staining, $1 \mathrm{hr}$ after the slices were stained and transferred to the interface chamber, or at the end of the recording session (after exposing the stained slices to light during the acquisition of 30 frames). Extracellular recordings of glomerular synaptic potentials in response to $\mathrm{ON}$ stimulation were performed as described previously (AroniadouAnderjaska et al., 1997b). There were no significant differences between recordings obtained before and after staining or after repeated illumination, suggesting that the staining procedure was not detrimental to the viability of the slices and that no appreciable phototoxicity occurred (data not shown).

Electrical stimulation. A bipolar stimulating electrode, insulated except at the tips, was placed in the $\mathrm{ON}$ layer to activate $\mathrm{ON}$ axons $(0.1-0.4 \mathrm{~mA}$; duration, $0.2-0.3 \mathrm{msec}$ ). Constant current pulses were delivered through an optically isolated stimulus isolator (Grass PSIU6, Quincy, MA) driven by a pulse generator (Grass S48). The pulse generator was also used to trigger image acquisition by the analog-to-digital (A/D) converter (see below). Placement of the stimulating electrode and stimulation intensity were adjusted to restrict the stimulation to only the superficial region of the olfactory nerve layer (ONL), to prevent direct activation by current spread of neuronal elements in deeper layers of the bulb.

Pharmacological and ionic manipulations. Pharmacological agents were prepared immediately before use from stock solutions and were dissolved in ACSF. These agents were added to the perfusate and delivered at a rate of $2 \mathrm{ml} / \mathrm{min}$. All pharmacological agents were obtained from Research Biochemicals (Natick, MA), except CGP35348 (gift of CibaGeigy, Basel) and fluorocitrate (Sigma, St. Louis, MO). Nominally calcium-free ACSF was prepared by replacing calcium with equimolar concentrations of magnesium and by the addition of 1 mM EGTA.

Optical recordings. Methods used for recording voltage-sensitive optical signals are similar to those described in detail elsewhere (Salzberg et al., 1977; Wu and Cohen, 1993). Slices were placed in the recording chamber at least $30 \mathrm{~min}$ before recordings commenced, to allow for the wash-out of excess dye and recovery. The recording chamber was fixed to the stage of an upright microscope (Leitz Orthoplan) rigidly mounted on a vibration-isolation table. A stabilized DC power source (Stahl 576, Port Chester, NY) was used to power a $100 \mathrm{~W}$ tungsten-halogen lamp, and the light from this lamp was band-limited with interference and heat filters; unless otherwise indicated, a $720 \pm 40 \mathrm{~nm}$ bandpass interference filter was used (Omega, Brattleboro, VT). Light transmitted through the preparation was collected through a $30 \times[0.9$ numerical aperture (NA);
LOMOrsqb] or a $40 \times(0.80$ NA; Olympus LUMPlanFl $)$ waterimmersion objective and projected onto a $10 \times 10$ square array of photodiodes (custom designed). The current output from each photodiode was separately converted to voltages, amplified in two separate stages $(\times 1000$; custom-designed electronics), multiplexed (MSXB018-01 multiplexer; Microstar Labs, Bellevue, WA), and digitized at 12 bit resolution with an A/D converter (DAP3000A/212, Microstar Labs). Data were collected and stored on an Intel 486-based personal computer, controlled by NeuroPlex software (Universal Imaging Corporation, West Chester, PA) designed by A. Cohen. Analyses of the data were performed on an Apple Macintosh computer, using routines developed in Igor (WaveMetrics, Lake Oswego, OR) and Transform (Fortner Research, Sterling, VA).

To identify precisely the regions in the slice from which optical recordings were collected, we used a custom-designed beam-splitting device (Microscope Services, Rockville, MD) to project simultaneously the images of the slice and the photodiode array onto the image plane of a CCD camera (Dage CCD72, Michigan City, IN). A fiber optic light source was used to illuminate the photodiode array, a procedure that enabled the simultaneous visualization of individual photodiodes and the identification of laminar boundaries in the slice (see Fig. $2 b$ ).

Unless otherwise indicated, all recordings were obtained at a sample rate of $6.2 \mathrm{kHz}$. All traces were obtained without signal averaging. To correct for spatial differences in illumination intensity and light path length, we divided the signal recorded from each detector by the resting light intensity calculated for the corresponding detector. The resting light intensity for each detector was calculated by subtracting the intensity values recorded while the shutter was closed from those recorded while the shutter was open, when no stimulation was applied. The unpaired Student's $t$ test was used for statistical analyses.

\section{RESULTS}

\section{Spatial distribution of optical signals}

Electrical stimulation in the ONL evoked a sequence of optically recorded responses the spatial and temporal distributions of which within the olfactory bulb were similar in all the slices studied ( $n=65$; Figs. 1, $2 a$ ). The waveform with the shortest onset latency was recorded in the ONL as a fast-rising signal (time to peak $=2.4 \pm 0.1 \mathrm{msec} ; n=41$ ) of short duration (half width $=2.8 \pm 0.2 \mathrm{msec} ; n=41)$. The sodium channel blocker tetrodotoxin (TTX; $0.5 \mu \mathrm{M}$ ) completely and reversibly abolished the optically recorded activity in all layers, including the signals recorded from the ONL (Fig. $1 b$ ). The finding that optical responses were suppressed by TTX indicates that these responses represent sodium channel-dependent membrane depolarization of $\mathrm{ON}$ axons and their postsynaptic targets and are not caused by direct activation of these neuronal elements by current spread from the stimulating electrode. Only signals recorded from photodiodes immediately over the stimulation site persisted in the presence of TTX, suggesting that these signals were evoked by direct depolarization of $\mathrm{ON}$ axons. In contrast, the ONLrecorded waveforms were not affected by bathing the slice in a nominally calcium-free solution (Fig. 1b). These findings indicate that the waveform recorded in the ONL represents a sodiumdependent compound action potential (cAP).

The cAP propagated from the stimulation site along the ONL and invaded the GL (Figs. 1, 2a). To estimate the conduction velocity of ON axons, we measured the time to peak of cAPs recorded by different photodiodes and plotted these values against the distance between the recording sites. This relationship was linear $\left(r^{2}=0.98 ; n=12\right)$, and the slope of the least-squares fit indicated a conduction velocity of $0.46( \pm 0.03) \mathrm{m} / \mathrm{sec}$. Similar values for the conduction velocity of $\mathrm{ON}$ axons were calculated with electrophysiological approaches in the cat (Freeman, 1972a) and rabbit (Nicoll, 1972). However, these values are faster than the conduction velocities of $0.25 \pm 0.01 \mathrm{~m} / \mathrm{sec}$ recently reported by Senseman (1996). The reason for this discrepancy is not clear; 


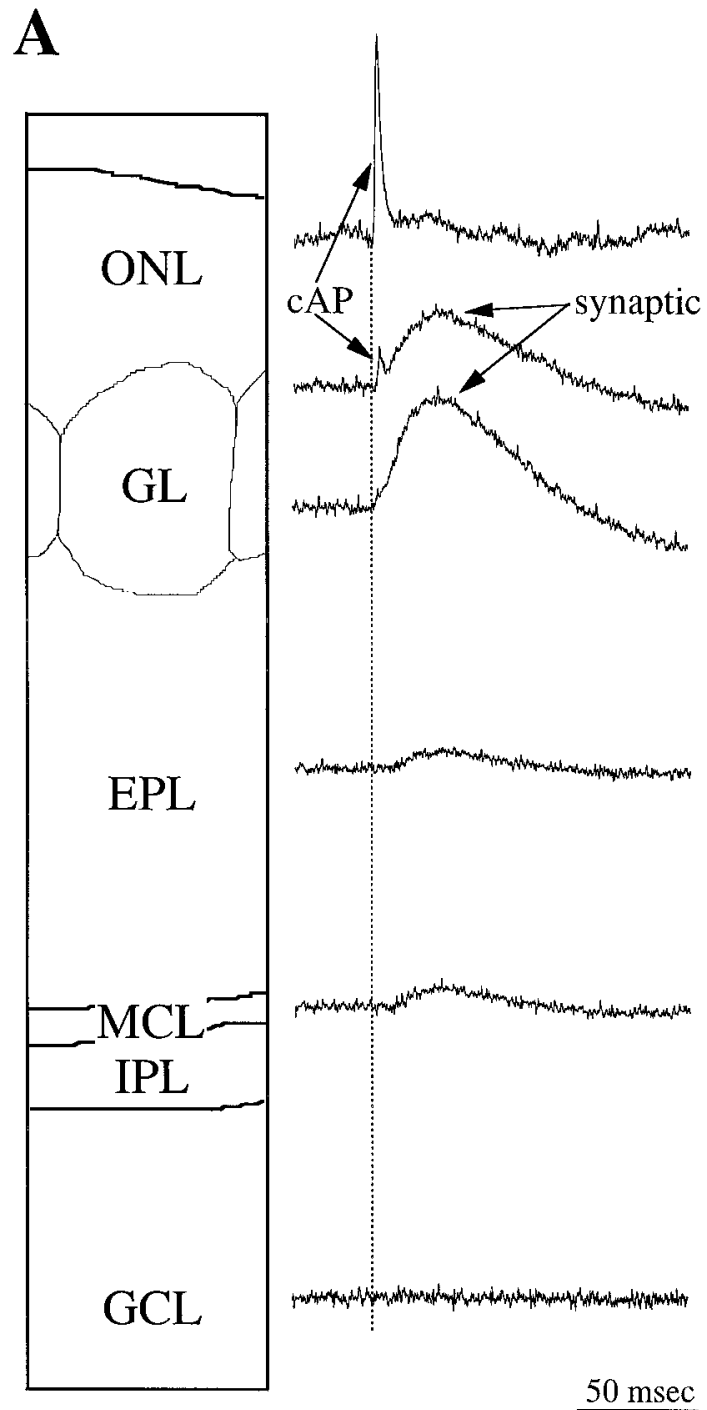

B
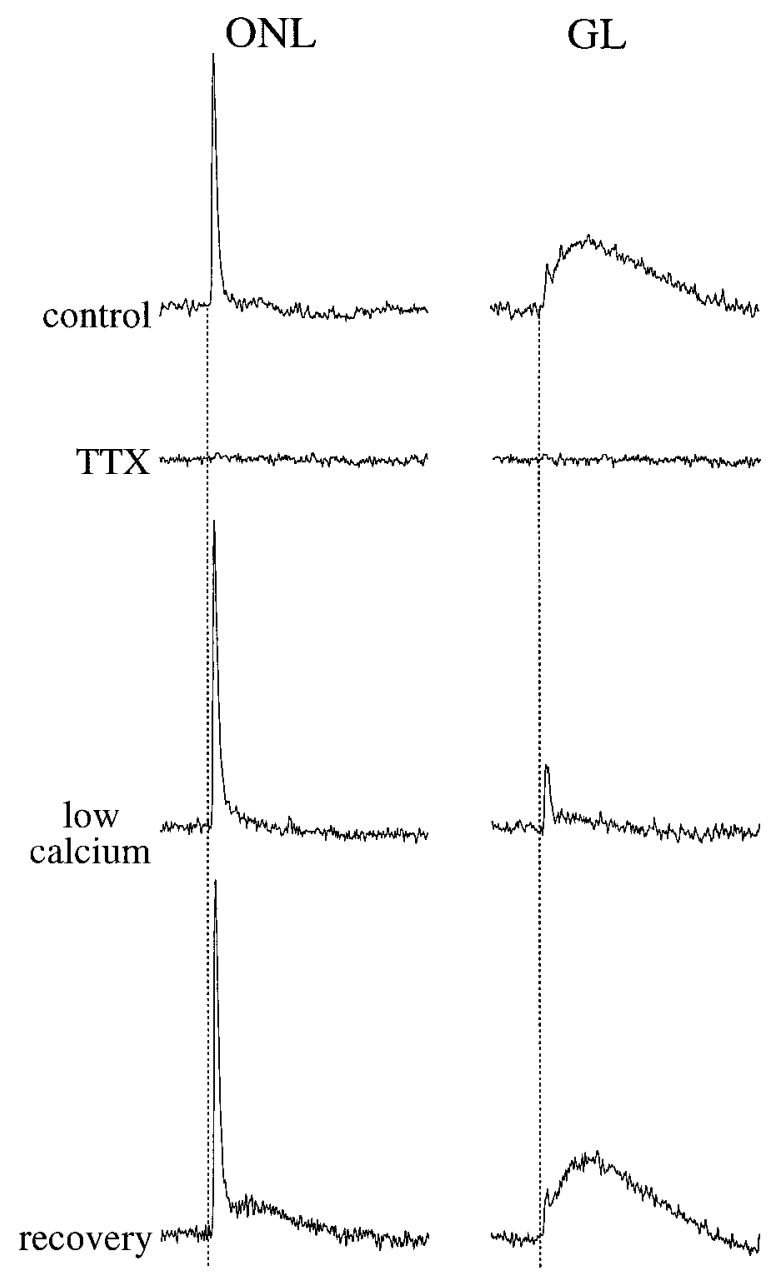

$50 \mathrm{msec}$

Figure 1. Origins of the optical responses. $A$, Signals evoked by olfactory nerve stimulation and recorded in the olfactory nerve $(O N L)$, glomerular $(G L)$, external plexiform $(E P L)$, mitral cell body $(M C L)$, internal plexiform $(I P L)$, and granule cell $(G C L)$ layers are shown. $A, B$, The fast compound action potential $(c A P)$ recorded in the $O N L$ and in all other layers is blocked by $0.5 \mu \mathrm{M}$ TTX $(B)$. The synaptic response, having a slower time course, is recorded in the $G L$, and its amplitude is maximal in the middle of this layer $(A)$. This response is suppressed in nominally calcium-free ACSF (low calcium; $B$ ). The amplitude and rise time of the synaptic responses are diminished in the $E P L$ and increase slightly in the $M C L$. No optical signal is detected in the GCL or the IPL (data not shown). Broken lines delineate the time of stimulation. In this and in all subsequent figures, positive deflections represent a decrease in light intensity.

in both studies, optical signals were recorded at room temperature, from in vitro slices of rat olfactory bulb stained with RH-155.

The amplitude of the cAP decreased gradually as it propagated along the ONL, distal to the stimulating electrode (Fig. 2a). This presumably reflects a reduction in the number of axons contributing to the optical signal, resulting from axons severed by the slicing procedure or leaving the ON bundles to invade the glomeruli (Hálasz and Greer, 1993). Within the glomeruli, the amplitude of the cAP decreased rapidly; cAPs were undetectable in the deep portion of the GL (Fig. 1a).

After the cAP, a second optically recorded waveform appeared in the GL. This depolarizing signal had a slower rise time (measured from onset to peak; $24.2 \pm 3.8 \mathrm{msec} ; n=41$ ) and longer duration (half width $=44.3 \pm 6.4 \mathrm{msec} ; n=41$ ) than did that of the cAP (Figs. 1, 2). In most optical records from the GL, this depolarizing response was followed by a long period $(\geq 200$ msec) in which the optical signal fell below baseline levels (see
Figs. 2, 3, 6). The nature of this late optical component is discussed below. The glomerular depolarizing response was completely suppressed in nominally calcium-free solution (Fig. 1b), indicating that it is dependent on synaptically mediated events within the glomeruli. This treatment had no effect on the cAP. The amplitude of the synaptically induced depolarizing component decreased sharply at the border of the GL and the external plexiform layer (EPL) and continued to decline within the deeper parts of the EPL (Figs. 1a, 2). A slight increase in the amplitude of these responses was recorded in the mitral cell body layer (Fig. $1 a)$. No detectable responses were recorded in the granule cell layer (Fig. 1a).

\section{Origin of optical signals}

Previous reports of electrophysiological recordings from mammalian olfactory bulbs (Mori, 1987; Nickell and Shipley, 1992; Aroniadou-Anderjaska et al., 1997b) and optical recordings from 
$\mathbf{A}$
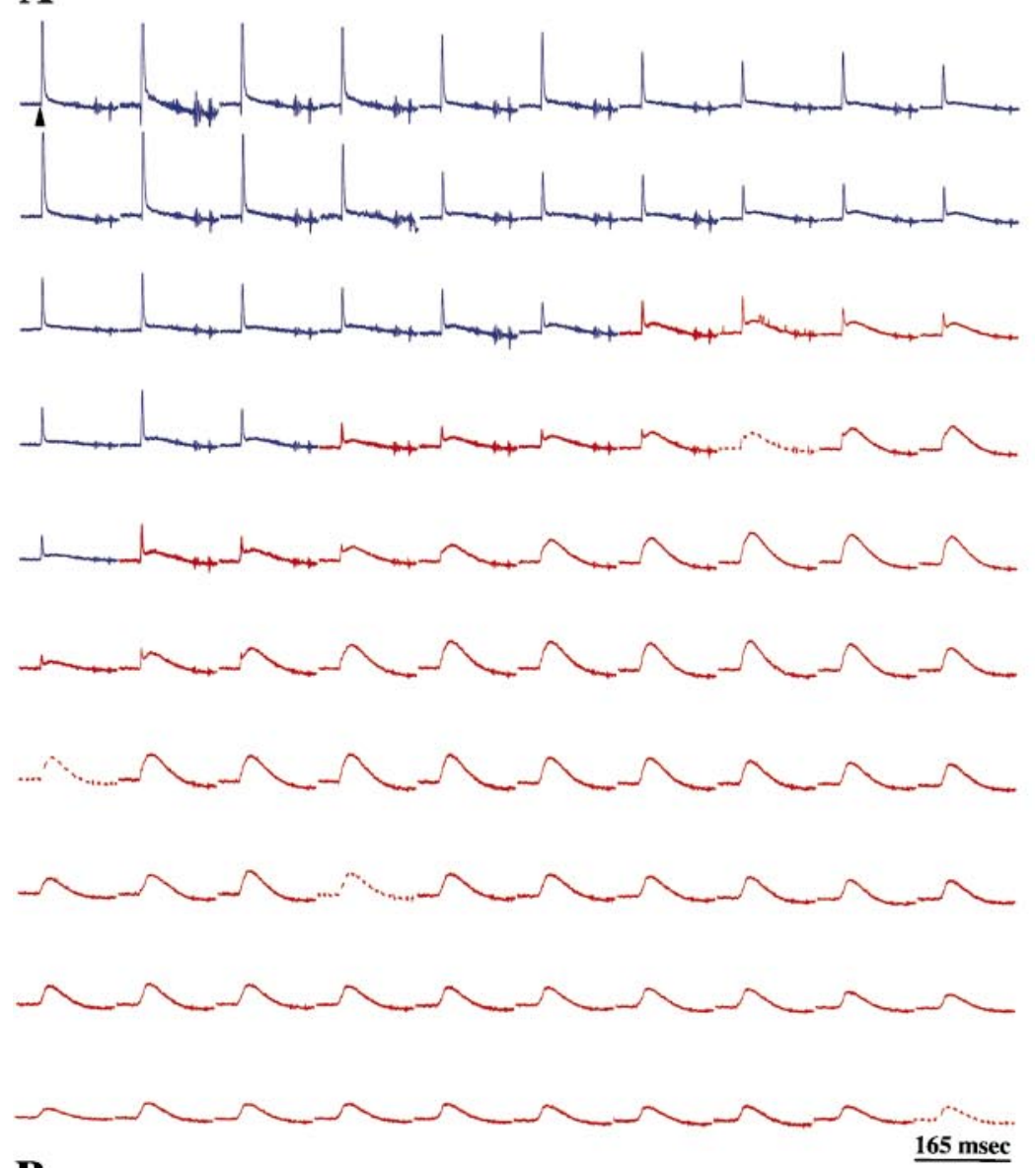

B

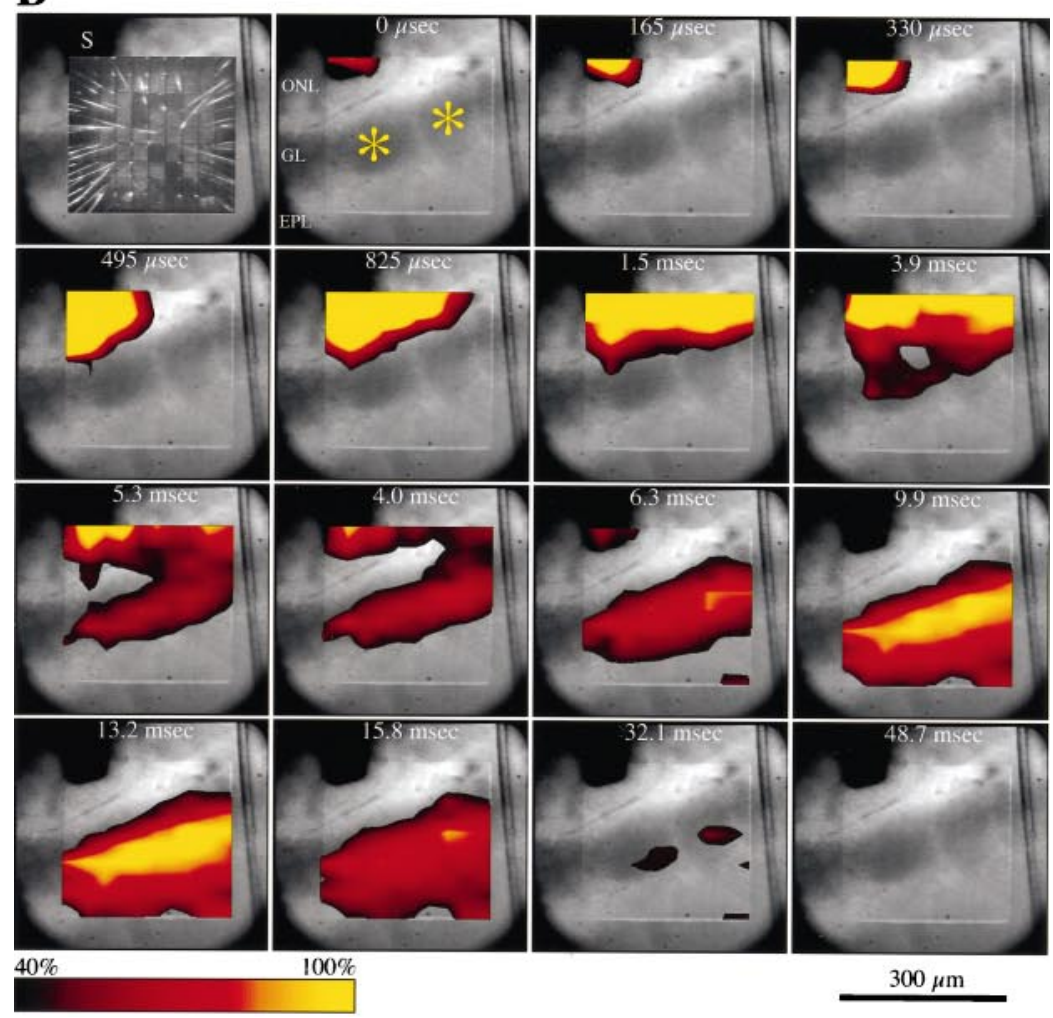

Figure 2. Voltage-sensitive optical signals recorded in an olfactory bulb slice. $A$, Optical signals recorded in response to stimulation of the olfactory nerve $(150 \mu \mathrm{A} ; 0.2 \mathrm{msec})$. The traces are arranged in a matrix corresponding to their origin within the 100 -element photodiode array. Signals recorded from the $O N L$ are depicted in blue, and recordings from the $G L$ and superficial EPL are in red. Traces from four defective detectors in the array were replaced by averaged signals from two adjacent detectors (broken lines). Time of stimulation is indicated by the arrowhead (top left). B, Spatiotemporal propagation of optical signals, calculated from the traces shown in $A$. Each panel depicts a digitized image of the slice and the photodiode array, acquired simultaneously through a beamsplitting device. Individual glomeruli are marked with an asterisk. Top left, The array was illuminated through a fiber optic to reveal the individual photodiodes and the wires emanating from them. The shadow formed by the stimulating electrode is indicated by $S$. Time intervals indicated are relative to the onset of stimulation $(t=0)$. Signal amplitudes are color-coded and interpolated, and a threshold function is used to only represent signals that are larger than $40 \%$ of the peak response recorded in the GL. Compound action potentials are truncated, resulting in saturation of the peak responses recorded in the $O N L$. Abbreviations are defined in the Figure 1 legend. 


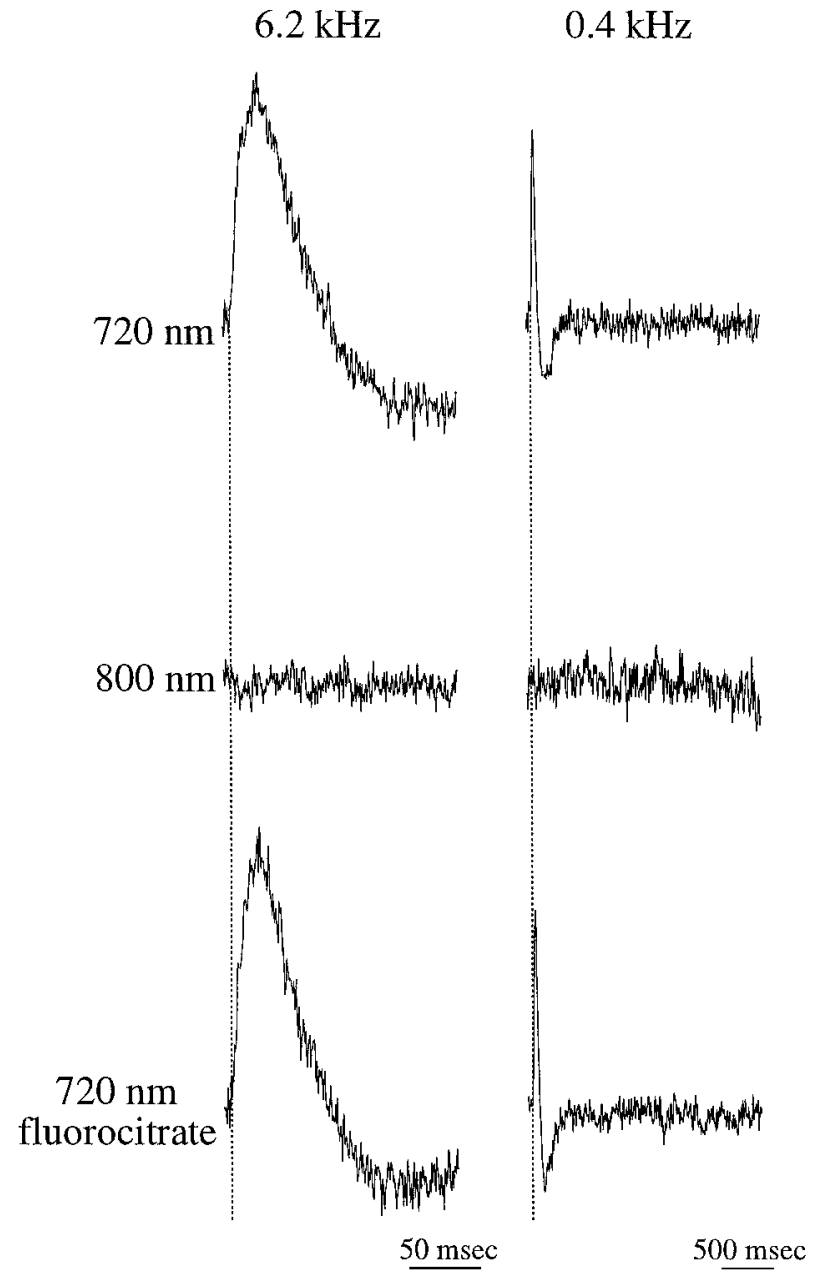

Figure 3. Responses in the glomerular layer represent dye-related optical signals from neuronal elements. Traces in the left column were digitized at faster rates and represent shorter sweeps, compared with those in the right column. All signals were recorded from the same photodiode in a single preparation. Signals recorded when the slice was illuminated at wavelengths optimized to the absorption spectrum of the dye $(720 \pm 40 \mathrm{~nm})$ were completely abolished when the wavelength was increased beyond the absorption spectrum of the dye $(\geq 800 \mathrm{~nm})$. Incubation of the slice for 75 min in $10 \mathrm{~mm}$ fluorocitrate, a selective inhibitor of glial cell respiration, had no effect on the recorded signals. Broken lines delineate the time of stimulation.

nonmammalian vertebrates (Kauer et al., 1987; Cinelli and Salzberg, 1990, 1992) describe both depolarizing and hyperpolarizing responses recorded at various layers of the olfactory bulb in response to $\mathrm{ON}$ stimulation. As described above, the depolarizing responses recorded in the GL were followed by an optical signal that fell below baseline. A similar negative signal was attributed previously to intrinsic optical signals, i.e., to nondye-related signals (Senseman, 1996). To determine whether intrinsic optical signals contributed to the waveforms recorded in our study, we tested the dependence of these signals on the illumination wavelength (Grinvald et al., 1982; Salzberg et al., 1985).

When the illumination was changed to a wavelength outside the absorption spectrum of the dye $(\geq 800 \mathrm{~nm})$, no optical signal was detected in the GL, even when the duration of the recordings exceeded $4 \mathrm{sec}$ (Fig. 3, right column). This suggests that the late negative component is not the result of intrinsic optical signals. It is therefore likely that this component represents a true late hyperpolarization of neuronal elements in the GL.

Dye-related optical signals may also originate from activation of glial cells (Konnerth et al., 1987; Cinelli and Salzberg, 1990). Several lines of evidence suggest that glia-related activity did not significantly contribute to the optical signals recorded in the present study. Incubation of the slices in $10 \mathrm{~mm}$ fluorocitrate, a glial toxin, for up to $90 \mathrm{~min}(n=4)$ had no effect on the recorded signals, including the late negative component (Fig. 3). At these concentrations, fluorocitrate selectively blocks the Krebs cycle in glial cells, without affecting neuronal activity (Stone et al., 1990). Furthermore, the optical responses recorded from glial cells are expected to exhibit a slow time course $(>1 \mathrm{sec})$ compared with that of neuronal responses (Konnerth et al., 1987). However, optical signals recorded in the GL had only a single depolarizing component, the duration of which was $75.3 \pm 14.2 \mathrm{msec}(n=41$; see Figs. 1-6). These findings suggest that the dye-related optical signals analyzed in the present study reflect neuronal responses that were not distorted by signals originating from glial cells.

\section{Glutamate receptors activated by $\mathrm{ON}$ inputs}

Several lines of anatomical and electrophysiological evidence indicate that transmission between $\mathrm{ON}$ axons and their postsynaptic targets in the glomeruli of the rat olfactory bulb is mediated by the excitatory neurotransmitter glutamate (for review, see Shipley and Ennis, 1996). Furthermore, we have recently shown that mitral and tufted cells respond to $\mathrm{ON}$ inputs via activation of both NMDA and non-NMDA glutamate receptors (Ennis et al., 1996; Aroniadou-Anderjaska et al., 1997b). In the present study, we determined whether juxtaglomerular neurons also respond to $\mathrm{ON}$ inputs via activation of these glutamate receptors.

Application of CNQX $(10 \mu \mathrm{M})$, an antagonist of non-NMDA ionotropic glutamate receptors, caused a significant decrease in the amplitude $(-75.2 \pm 22.1 \% ; p<0.001)$ of the synaptically induced optical responses recorded in the GL $(n=11$; Fig. $4 A)$. CNQX had no effect on either the time course or amplitude of the cAP. The amplitude of optical signals recorded in the presence of CNQX was increased (by $37.4 \pm 9.3 \% ; p<0.01 ; n=4$ ) in the presence of a nominally magnesium-free solution (Fig. 4A), a condition that enhances the activation of NMDA receptors (Collingridge and Bliss, 1985). Indeed, this residual component was nearly completely suppressed $(-81.7 \pm 12.2 \%$; $p<0.001)$ by the addition of AP-5 $(100 \mu \mathrm{M})$, an antagonist of NMDA receptors $(n=9$; Fig. $4 A$ ). The CNQX-sensitive component was isolated by applying AP-5 (100 $\mu \mathrm{M}$; Fig. $4 B)$, revealing an optical signal the amplitude of which was reduced by $69.2 \pm 12.2 \%(n=3 ; p<$ $0.01)$ relative to that of control; this CNQX-sensitive component was greatly attenuated $(-92.6 \pm 9.3 \% ; n=3 ; p<0.001)$ by adding $10 \mu \mathrm{M}$ CNQX (Fig. $4 B$ ). These findings indicate that $\mathrm{ON}$ inputs activate both NMDA and non-NMDA receptor-mediated currents in the GL.

\section{GABA-mediated inhibition}

Anatomical and electrophysiological data show that mitral cells receive inhibitory, dendrodendritic synapses from GABAcontaining granule cells (for review, see Mori, 1987; Shepherd, 1990; Shipley et al., 1996). Less information is available about the function of inhibition in the GL itself, which is mediated by periglomerular neurons. Anatomical studies have shown that many periglomerular cells contain GABA (Macrides and Davis, 1983; Mugnaini et al., 1984) and form reciprocal dendrodendritic synapses with the intraglomerular apical dendrites of mitral and 
A

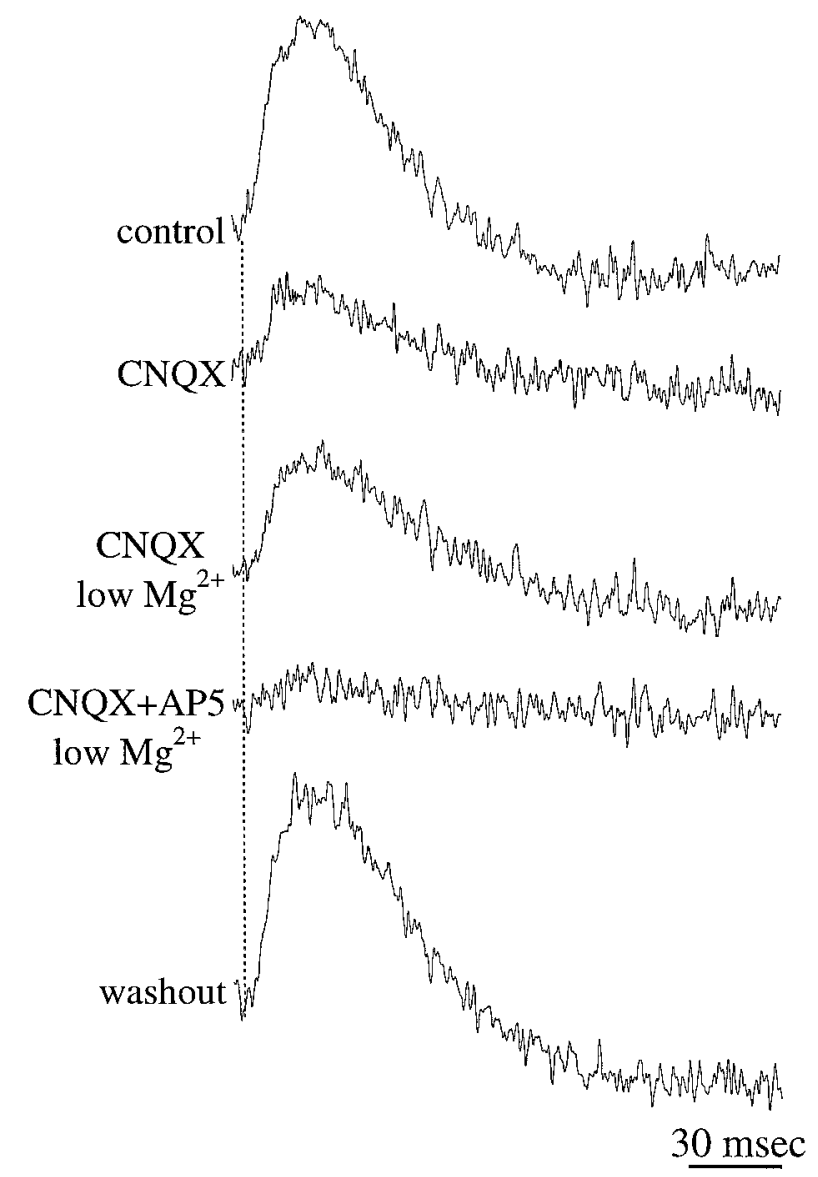

$\mathrm{B}$

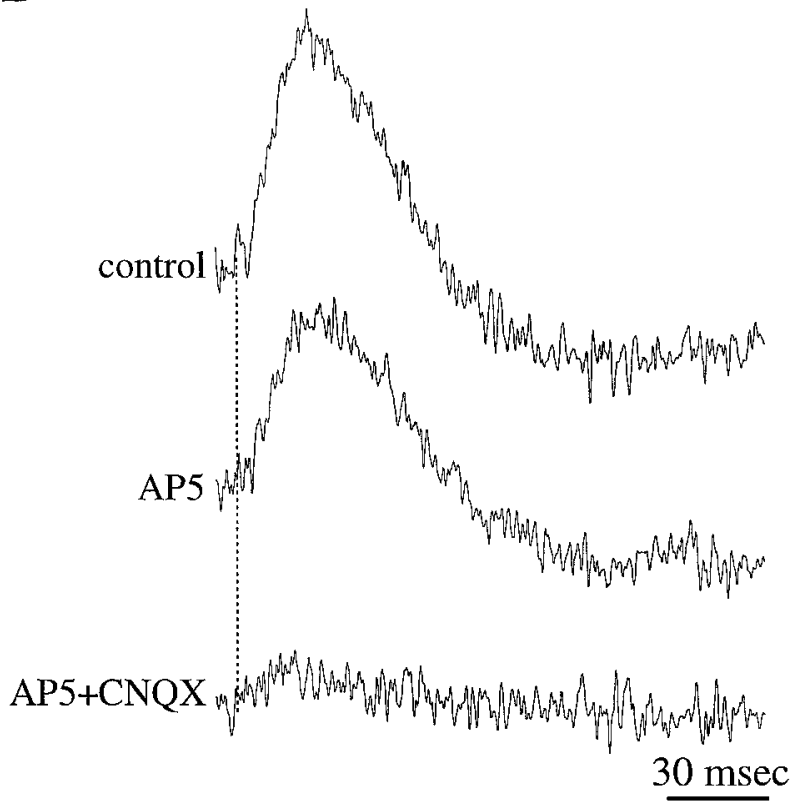

Figure 4. Olfactory nerve inputs evoke both NMDA and non-NMDA receptor-mediated responses in the GL. $A$, Application of the non-NMDA glutamate receptor antagonist CNQX $(10 \mu \mathrm{M})$ reveals a small-amplitude response, which was enhanced in nominally magnesium-free solution (low $\left.\mathrm{Mg}^{2+}\right)$. This component of the response was suppressed by the NMDA glutamate receptor antagonist AP-5 $(100 \mu \mathrm{M})$. B, The response mediated by non-NMDA receptors is revealed by application of AP-5 $(100 \mu \mathrm{M})$; this component is suppressed by addition of CNQX (10 $\mu \mathrm{M})$.

tufted cells. Periglomerular cells receive direct input from $\mathrm{ON}$ axons, suggesting that olfactory stimulation results in the release of GABA from these cells (Pinching and Powell, 1971; Freeman, 1974a; Getchell and Shepherd, 1975; Wellis and Scott, 1990).

To investigate the role of GABAergic inhibition in the GL, we applied specific GABA receptor agonists or antagonists. The $\mathrm{GABA}_{\mathrm{A}}$ receptor antagonist bicuculline methiodide $(50 \mu \mathrm{M} ; n=$ 7) produced a small increase in the amplitude $(11.2 \pm 2.6 \% ; p=$ $0.08)$ and duration $(14.0 \pm 4.7 \% ; p=0.11)$ of the glomerular responses (Fig. $5 A$ ). In contrast, the $\mathrm{GABA}_{\mathrm{B}}$ receptor agonist baclofen $(5 \mu \mathrm{M} ; n=11)$ resulted in a significant suppression of these responses $(-83.7 \pm 19.4 \% ; p<0.005)$, and in many cases this agonist completely suppressed the responses (see Figs. 5-6). The effects of baclofen were manifest within 3-5 min after the drug was applied and reversed completely within 5-10 min after wash-out of the drug (Fig. 5A). The suppressive effects of baclofen were reversed by the addition of the $\mathrm{GABA}_{\mathrm{B}}$ receptor antagonist CGP35348 (500 $\mu \mathrm{M} ; n=5$; Fig. 6a1,b1). However, when CGP35348 was applied alone, it produced only a small increase $(9.3 \pm 4.2 \% ; p=0.14 ; n=5)$ in the amplitude of the glomerular responses (Fig. 6a1,b1).

Neither of the GABA receptor antagonists (bicuculline or CGP35348) had any effect on the late, slow hyperpolarizing component of the glomerular response (Figs. 5-6). This suggests that the hyperpolarizing response is not directly mediated by GABAergic inhibition. In contrast, baclofen, in addition to suppressing the depolarizing component of the response, also suppressed this late hyperpolarizing component (Figs. 5-6). The effects of baclofen on the hyperpolarizing response suggest that this response is dependent on the earlier, depolarizing component of the glomerular response. It is possible that the hyperpolarizing component represents outward currents, such as those carried through slowly inactivating potassium channels, the activation of which is dependent on synaptically induced depolarization.

We recently reported that bicuculline selectively enhances $(\sim 25 \%$ increase) the NMDA receptor-mediated response of mitral cells to ON inputs (Aroniadou-Anderjaska et al., 1997b). To test the effects of bicuculline on NMDA receptor-mediated responses in the GL, we isolated these responses by application of CNQX $(10 \mu \mathrm{M})$ in the presence of a nominally magnesiumfree solution (Fig. $5 B$ ). Addition of $50 \mu \mathrm{M}$ bicuculline produced a small increase in the amplitude of the responses $(16.7 \pm 6.2 \%$; $n=3 ; p=0.13$ ).

\section{Presynaptic inhibition of ON inputs}

Because $\mathrm{GABA}_{\mathrm{B}}$ receptors are distributed almost exclusively in the GL of the olfactory bulb (Bowery et al., 1987), the potent 
A

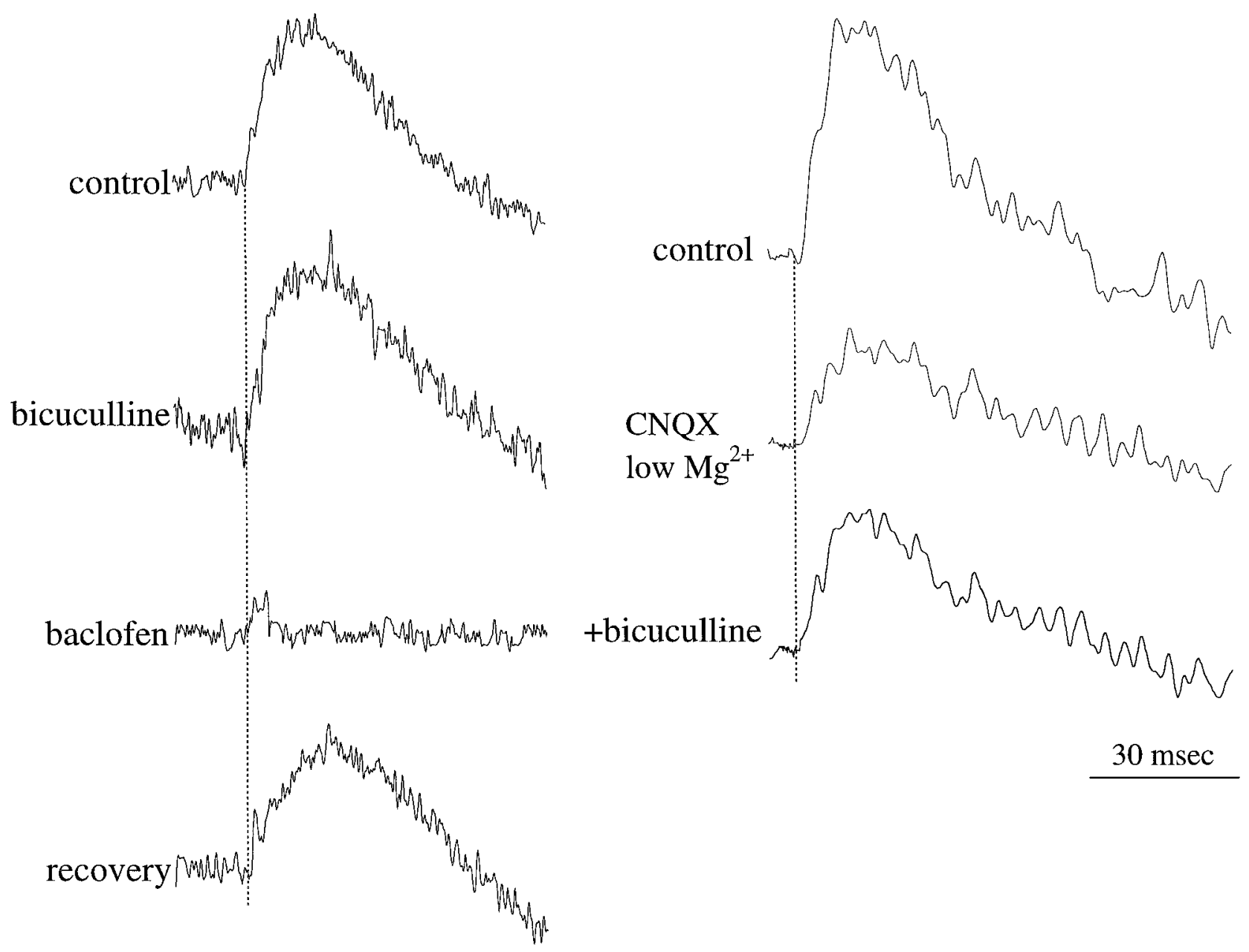

$50 \mathrm{msec}$

Figure 5. GABA-mediated inhibition of olfactory nerve inputs to the GL. $A$, The GABA receptor antagonist bicuculline (50 $\mu \mathrm{M})$ produced a slight increase in the amplitude and duration of the GL response. In contrast, the GABA $\mathrm{G}_{\mathrm{B}}$ receptor agonist baclofen $(5 \mu \mathrm{M})$ suppressed this response. $B$, Bicuculline produced a small increase in the NMDA receptor-mediated component, isolated in the presence of CNQX (10 $\mu \mathrm{M})$ and nominally magnesium-free solution (low $\mathrm{Mg}^{2+}$ ).

effects of baclofen and CGP35348 most likely represent actions on $\mathrm{GABA}_{\mathrm{B}}$ receptors located on neuronal elements within this layer. These receptors may be present on any of the neuronal elements in this layer: GABAergic periglomerular cells, juxtaglomerular excitatory interneurons, or the dendrites of mitral and tufted cells. $\mathrm{GABA}_{\mathrm{B}}$ receptors may also be located on $\mathrm{ON}$ axon terminals, such that GABA released from periglomerular neurons presynaptically inhibits these terminals. The dramatic attenuation of the responses by baclofen (Figs. 5-6) is consistent with a presynaptic locus of $\mathrm{GABA}_{\mathrm{B}}$ receptors.

One approach to study presynaptic inhibition is to test the role of GABA in modulating paired-pulse depression (PPD), which is mediated in many cases by presynaptic inhibition (see Alger, 1991; Misgeld et al., 1995). In the olfactory bulb, a conditioning stimulus of the ON inhibits responses to a subsequent (test) ON stimulus (Freeman, 1974a,b; Cinelli and Salzberg, 1992; Nickell et al., 1994). This PPD is manifested in recordings of field potentials, single-unit and intracellular responses, and voltagesensitive optical signals (for review, see Senseman, 1996). It has been proposed that PPD represents sustained depolarization of ON axons because of the accumulation of potassium or other neuroactive substances in the ON layer (Freeman, 1974b; Jahr and Nicoll, 1981). However, recordings of the cAP, isolated by removing calcium from the bath, failed to provide evidence of long-lasting depolarization of ON axons (Fig. 1). In the present study, we investigated the role of GABA in mediating PPD.

Stimulation of the ON with a pair of pulses, delivered at intervals ranging from 100 to $500 \mathrm{msec}$, caused a prominent PPD; responses to the test pulse decreased to $15.6 \pm 13.6 \%$ relative to responses to the conditioning pulse ( $n=7$; Fig. $6 a 2, b 2)$. This PPD was significantly attenuated by application of the $\mathrm{GABA}_{\mathrm{B}}$ receptor antagonist CGP35348 (Fig. 6a2,b2); the amplitudes of the test responses increased to $85.2 \pm 22.4 \%$ of the conditioning responses $(n=5)$. CGP35348 was also effective in attenuating the depression induced by trains of four to five pulses (Fig. 6b2). The finding that CGP35348 significantly enhanced test responses but had only a minor effect on responses to a single pulse (see above) supports the conclusion that $\mathrm{GABA}_{\mathrm{B}}$ receptors are located pre- 
A1
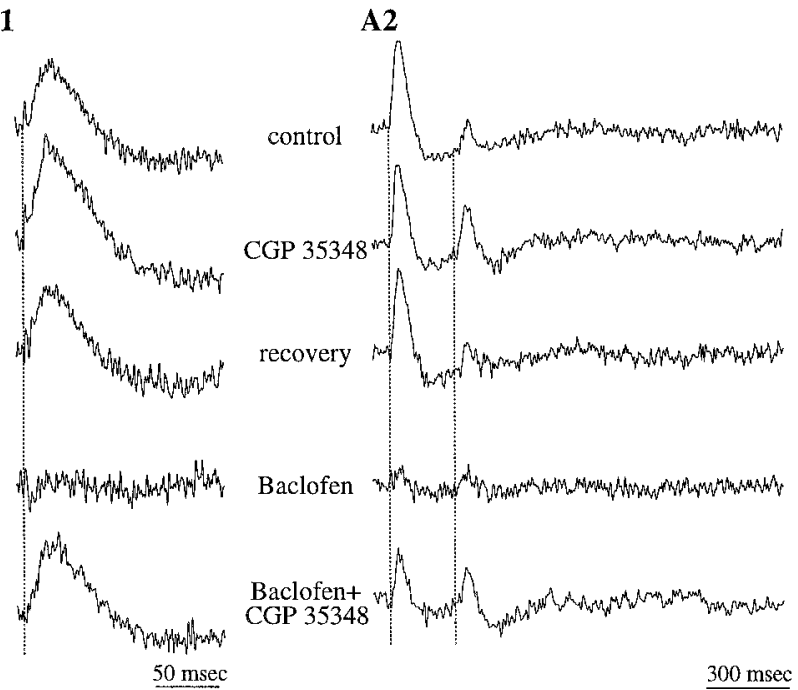

B1

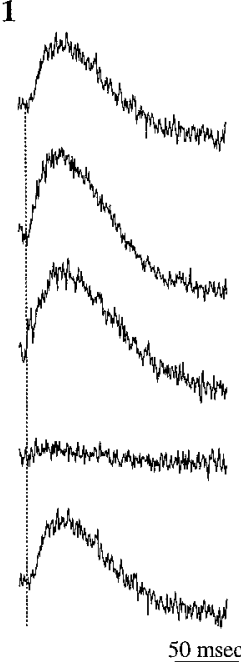

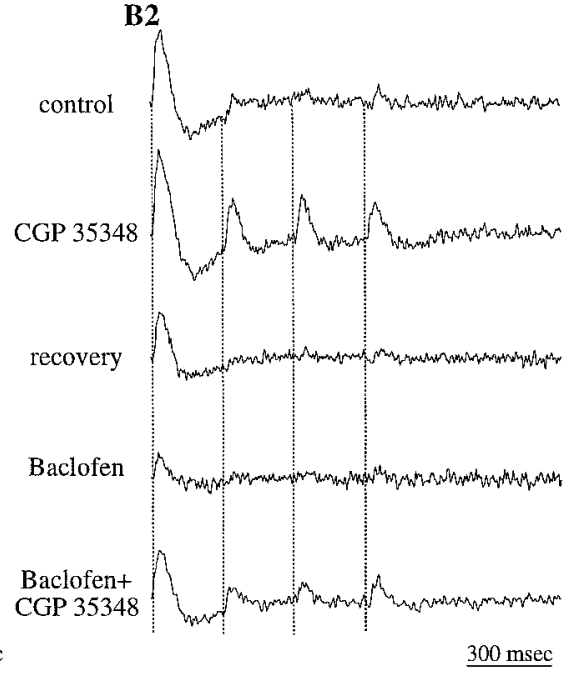

Figure 6. $\mathrm{GABA}_{\mathrm{B}}$ receptor-mediated inhibition may act presynaptically on olfactory nerve terminals. Data are from two different slices $(A, B) ; A 1$ and $B 1$ depict traces digitized at faster rates and representing shorter sweeps compared with those in $A 2$ and $B 2$. The $\mathrm{GABA}_{\mathrm{B}}$ receptor antagonist CGP35348 $(500 \mu \mathrm{M})$ produced a small increase in the amplitude of GL responses evoked by a single stimulus pulse in the ONL $(A 1, B 1)$. In contrast, the prominent paired-pulse depression evoked by trains of two $(A 2)$ or four (B2) stimuli was significantly decreased by CGP35348. The $\mathrm{GABA}_{\mathrm{B}}$ receptor agonist baclofen suppressed the responses to both single pulses and trains of stimuli. CGP35348 reversed the effects of baclofen.

synaptically on ON axon terminals. Thus, GABA released from periglomerular cells in response to a conditioning pulse would presynaptically inhibit glutamate release from the terminals of ON axons, thereby suppressing the response to test pulses.

\section{DISCUSSION}

\section{Origin of the optical signals}

ON axons synapse with various neuronal elements within the GL, including the dendrites of projection neurons (mitral and tufted cells), the somata of which are in deeper layers, and juxtaglomerular neurons (for review, see Shepherd, 1990; Shipley and Ennis, 1996). Within an individual glomerulus, there are $\sim 1000$ juxtaglomerular neurons and 75-100 apical dendrites of projection

cells (see Allison and Warwick, 1949) (E. Meisami, personal communication). Because the amplitude of the optical signal is directly proportional to the surface area of the membranes from which the signal is recorded (assuming uniform dye binding) (Salzberg et al., 1973; Grinvald et al., 1988), most of the optically recorded response in this layer should originate from juxtaglomerular cells. However, we cannot exclude the possibility that some component of the responses originates from the apical dendritic tufts of mitral and tufted cells.

ON stimulation evoked long-duration depolarizations in the GL. Senseman (1996) conjectured that these sustained depolarizations reflect activation of voltage-dependent $\mathrm{Cl}^{-}$outward currents in juxtaglomerular neurons. These sustained depolarizations do not reflect the slow time course of NMDA receptor activity, because the duration of the responses was not affected by suppressing NMDA receptors with AP-5 (Fig. 4B). Alternatively, the sustained depolarizations may reflect asynchronous postsynaptic activity, reverberating synaptic activity in the GL, or repetitive firing in individual juxtaglomerular neurons. Indeed, we have recently demonstrated that some classes of juxtaglomerular neurons respond to $\mathrm{ON}$ stimulation with long bursts of action potentials (Shipley et al., 1997).

Small-amplitude optical signals were recorded in the EPL. This is in agreement with a previous study (Senseman, 1996) reporting that the amplitude of ON-evoked optical signals decreases dramatically below the GL and EPL border. The EPL is composed primarily of dendrites belonging to mitral and tufted cells and granule cells (see Reese and Shepherd, 1972; Shipley and Ennis, 1996). The small amplitude of responses recorded in this layer may be attributable to the small membrane potential changes produced by these dendrites, compared with the suprathreshold responses of neurons in the GL. The relatively low density of tufted cell somata in the EPL may also contribute to this relatively small signal. A small increase in the amplitude of the optical signals was recorded in the mitral cell layer, and this increase may be because of the high packing density and large size of the somata of mitral cells. In contrast, in similar studies in the salamander and skate olfactory bulb, large synaptic responses were recorded throughout the EPL (Cinelli and Salzberg, 1990, 1992). The wider distribution of responses in these nonmammalian species most likely reflects differences in the distribution of glomeruli and of dendrites of mitral and tufted cells compared with that of the rat olfactory bulb. Cinelli and Salzberg (1992) suggested that, in the salamander, some of the responses recorded deep to the glomerular layer reflect activation of calcium currents in the dendrites of mitral and tufted cells. We recently reported evidence, in the rat olfactory bulb, of activation of voltagedependent calcium channels in the distal apical dendrites of mitral cells in response to ON stimulation (Carlson et al., 1997). However, in the present study, we found no evidence of this phenomenon, presumably because the postsynaptic depolarization of mitral cells produces relatively small optical signals.

Although recordings of field potentials demonstrate that $\mathrm{ON}$ stimulation evokes activity in granule cells (Freeman, 1972b; Mori, 1987; Aroniadou-Anderjaska et al., 1997b), voltagesensitive optical signals were not detected in the GCL. This suggests that the dendrodendritic inputs from mitral cells failed to induce synchronous depolarization in a sufficient population of granule cells to evoke a detectable signal. Alternatively, the inputs from the lateral dendrites of mitral cells may evoke only a local depolarization in the dendrites of granule cells, and this depolarization fails to propagate to granule cell somata (see Rall 
and Shepherd, 1968). It could be argued that a significant population of these dendrodendritic synapses was compromised by truncation of the lateral dendrites of mitral cells in the slice preparation. This is unlikely, however, because a robust activation of these synapses is evident in recordings of field potentials from the same slice preparation (Aroniadou-Anderjaska et al., 1997b).

\section{Glutamate-mediated responses in the GL}

Because most of the optical signal recorded in the GL is thought to represent activity in juxtaglomerular neurons, it was possible to investigate the types of glutamate receptors mediating excitatory inputs to these neurons. Voltage-sensitive optical responses to ON stimulation were dominated by signals mediated by nonNMDA glutamate receptors, whereas activation of NMDA receptors produced a smaller response, even when the magnesium block of these receptors was relieved (Fig. 4). The smaller amplitude of the NMDA receptor component may indicate that juxtaglomerular neurons express a relatively low density of NMDA receptors. Alternatively, NMDA receptors may be expressed preferentially in a small population of juxtaglomerular neurons. This would be in agreement with findings that juxtaglomerular neurons are a heterogeneous population, both in terms of their neurochemical content and their electrophysiological properties (Kosaka et al., 1995; Heyward et al., 1996).

It is also possible that the small amplitude, NMDA receptormediated responses may reflect activity in the apical dendritic tuft of mitral and tufted cells, the small surface area of which contributes little to the optical signals. We have recently demonstrated that these dendritic segments generate NMDA receptormediated responses after ON stimulation (AroniadouAnderjaska et al., 1997b). This would suggest that non-NMDA glutamate receptors are expressed both in mitral and tufted and in juxtaglomerular neurons, whereas NMDA receptors in the GL are preferentially localized in the apical dendritic tufts of mitral and tufted cells. Additional experiments are needed to distinguish among these alternatives.

The pharmacologically isolated NMDA and non-NMDA receptor-mediated optical signals differed in their amplitude but were of similar duration (Fig. 4). Field-potential recordings reveal that the NMDA receptor-mediated response consists of (1) an initial component of relatively large amplitude and of a duration similar to that of the NMDA component recorded in the present study [compare Fig. $4 A$ with Aroniadou-Anderjaska et al. (1997b), their Fig. 2], (2) followed by a low amplitude, longduration component. It is likely that this second component produces an optical signal that is below the resolution of the imaging system and that only the initial component is revealed in optical recordings. This would explain the similarity in the duration of the optically recorded NMDA and non-NMDA receptormediated components.

\section{GABA-mediated inhibition in the GL}

Optical imaging was also used to investigate GABA-mediated inhibition in the GL. Application of the $\mathrm{GABA}_{\mathrm{A}}$ receptor antagonist bicuculline had only a small effect on the ON-evoked responses recorded in this layer (Fig. 5). We have recently demonstrated, with the use of field-potential recordings, that bicuculline increases the amplitude of the NMDA component of the response of mitral and tufted cells to ON stimulation by $\sim 25 \%$ but has little or no effect on the AMPA/kainate component of the response (Aroniadou-Anderjaska et al., 1997b). In the present study, bicuculline caused a small ( $\sim 17 \%$ increase), although not statistically significant, enhancement of the isolated NMDA component recorded optically in the GL (Fig. 5B). If, as discussed above, NMDA receptors are expressed preferentially on the apical dendritic tufts of projection neurons, the small effect of bicuculline may be attributable to the small contribution of these dendrites to the optical response (see above). Taken together, these findings suggest that $\mathrm{GABA}_{\mathrm{A}}$ receptors are preferentially located on the apical dendrites of projection neurons where they modulate NMDA receptors, whereas juxtaglomerular neurons express few if any $\mathrm{GABA}_{\mathrm{A}}$ receptors. Alternatively, the heterogeneity of juxtaglomerular cells (discussed above) suggests that $\mathrm{GABA}_{\mathrm{A}}$ receptors may be expressed preferentially in a subset of these neurons.

In contrast to the limited role of $\mathrm{GABA}_{\mathrm{A}}$ receptors in juxtaglomerular neurons, modulators of $\mathrm{GABA}_{\mathrm{B}}$ receptors had profound effects on synaptic responses in these cells. ON-evoked responses were significantly attenuated and frequently abolished by application of the $\mathrm{GABA}_{\mathrm{B}}$ receptor agonist baclofen. This effect was reversed by the $\mathrm{GABA}_{\mathrm{B}}$ receptor antagonist CGP35348. With the use of electrophysiological approaches, we recently demonstrated a similar effect of $\mathrm{GABA}_{\mathrm{B}}$ receptormediated inhibition in the rat olfactory bulb (Nickell et al., 1994); baclofen suppressed field potentials recorded in response to ON stimulation in vivo and both spontaneous and evoked firing of mitral cells recorded in vitro.

Although $\mathrm{GABA}_{\mathrm{B}}$ receptors may be located on any of the neuronal elements within the GL, several lines of evidence suggest that they are involved in presynaptic inhibition of $\mathrm{ON}$ axon terminals. In the present study, the $\mathrm{GABA}_{\mathrm{B}}$ receptor antagonist CGP35348 significantly attenuated PPD but had little effect on single responses to $\mathrm{ON}$ stimulation. If $\mathrm{GABA}_{\mathrm{B}}$ receptors were located on postsynaptic neuronal elements in the GL, the $\mathrm{GABA}_{\mathrm{B}}$ antagonist would be expected to affect responses to single ON stimuli by suppressing the response of postsynaptic receptors to GABA released from periglomerular cells. Therefore, the attenuation of PPD by CGP35348 likely reflects suppression of $\mathrm{GABA}_{\mathrm{B}}$ receptors expressed by $\mathrm{ON}$ axon terminals. The nearly complete suppression of GL responses to ON stimulation by baclofen is also consistent with a presynaptic locus of $\mathrm{GABA}_{\mathrm{B}}$ receptors. Finally, we recently reported that, in slices of rat olfactory bulb, baclofen has little effect on field potentials recorded in the GL in response to antidromic stimulation of mitral cells (Aroniadou-Anderjaska et al., 1997a). Similar findings were reported in the rat olfactory bulb in vivo (Nickell et al., 1994) and in the frog olfactory bulb (Potapov, 1985). Because both ON axons and the apical dendrites of mitral cells may provide input to the same population of juxtaglomerular neurons, the differential effect on baclofen on responses to stimulation of these pathways further supports the conclusion that $\mathrm{GABA}_{\mathrm{B}}$ receptors are located presynaptically on $\mathrm{ON}$ axon terminals.

Presynaptic inhibition of excitatory inputs, mediated by $\mathrm{GABA}_{\mathrm{B}}$ receptors, has been described in a number of brain regions, including the hippocampus (Isaacson et al., 1993), striatum (Calabresi et al., 1991), thalamus (Emri et al., 1996), cerebellum (Dittman and Regehr, 1996), and supraoptic nucleus (Kombian et al., 1996). In addition, $\mathrm{GABA}_{\mathrm{B}}$ presynaptic receptors mediate the PPD of inhibitory inputs from GABAergic neurons in the hippocampus (for review, see Alger, 1991; Thompson et al., 1993; Misgeld et al., 1995). Although anatomical data suggest that $\mathrm{ON}$ axon terminals do not receive classical chemical synapses (Pinching and Powell, 1971; White, 1972), GABA may 
diff use from nearby release sites to activate $\mathrm{GABA}_{\mathrm{B}}$ receptors on ON axon terminals (see Faber and Korn, 1988). It is therefore likely that PPD in the olfactory bulb is mediated, in large part, by $\mathrm{GABA}_{\mathrm{B}}$ receptors on $\mathrm{ON}$ axon terminals. These receptors may be activated by GABA released from periglomerular neurons after ON stimulation.

CGP35348 did not completely block the PPD. This may be because of an incomplete antagonism of the $\mathrm{GABA}_{\mathrm{B}}$ receptor by this substance, resulting from the relatively low affinity of CGP35348 for the $\mathrm{GABA}_{\mathrm{B}}$ receptor (Olpe et al., 1994). Alternatively, mechanisms other than presynaptic $\mathrm{GABA}_{\mathrm{B}}$ receptors also contribute to PPD. For example, PPD may also be mediated by presynaptic dopamine receptors of the $\mathrm{D}_{2}$ and $\mathrm{D}_{3}$ subtype, which are localized in both the ONL and the GL (Nickell et al., 1991). This hypothesis is supported by the demonstration of $\mathrm{D}_{2}$ receptor mRNA transcripts in olfactory receptor neurons and by findings that $\mathrm{D}_{2}$ receptor binding in the ONL and glomeruli is eliminated after lesions of the olfactory epithelium (see Shipley and Ennis, 1996). In addition, $D_{2}$ receptor agonists suppress the response of mitral cells to ON stimulation, and this effect is prevented by $\mathrm{D}_{2}$ receptor antagonists (Zimmer et al., 1995). Thus, it is possible that periglomerular neurons, many of which contain dopamine in addition to GABA (see Macrides and Davis, 1983; Shipley and Ennis, 1996), corelease dopamine and GABA, both of which act presynaptically on $\mathrm{ON}$ axon terminals to cause PPD.

This study was designed to investigate the physiology of synaptic interactions in glomeruli of the rat olfactory bulb. The results suggest that $\mathrm{ON}$ axons form glutamatergic synapses with juxtaglomerular neurons, which express both non-NMDA and NMDA receptors. The juxtaglomerular neurons appear to express little or no $\mathrm{GABA}_{\mathrm{A}}$ receptors. ON inputs to periglomerular neurons cause the release of GABA from these cells, which may activate presynaptic $\mathrm{GABA}_{\mathrm{B}}$ receptors located on $\mathrm{ON}$ axon terminals. This provides a potent mechanism for feedback modulation of sensory inputs to the olfactory bulb.

\section{REFERENCES}

Alger BE (1991) Gating of GABAergic inhibition in hippocampal pyramidal cells. Ann NY Acad Sci 627:249-263.

Allison AC, Warwick TT (1949) Quantitative observations on the olfactory system of the rabbit. Brain 72:186-197.

Aroniadou-Anderjaska V, Ennis M, Keller A, Shipley MT (1997a) $\mathrm{GABA}_{\mathrm{B}}$ receptor-mediated inhibition in the glomeruli of the rat olfactory bulb (OB). Soc Neurosci Abstr 23:1268.

Aroniadou-Anderjaska VA, Ennis M, Shipley MT (1997b) Glomerular synaptic responses to olfactory nerve input in rat olfactory bulb slices. Neuroscience 79:425-434.

Bowery NG, Hudson AL, Price GW (1987) GABA and $_{\text {GABA }}$ B receptor site distribution in the rat central nervous system. Neuroscience 20:365-383.

Calabresi P, Mercuri NB, De Murtas M, Bernardi G (1991) The involvement of GABA systems in feedback regulation of glutamate- and GABA-mediated synaptic potentials in rat neostriatum. J Physiol (Lond) 440:581-599.

Carlson GC, Heyward P, Ennis M, Shipley MT, Keller A (1997) Active membrane properties in mitral cells of the rat olfactory bulb. Soc Neurosci Abstr 23:1268.

Cinelli AR, Salzberg BM (1987) Optical recording of electrical activity in slices of mammalian olfactory structures: extrinsic signals from olfactory bulb and pyriform and sulcal cortices of the mouse. Soc Neurosci Abstr 13:1411.

Cinelli AR, Salzberg BM (1990) Multiple site recording of transmembrane voltage (MSORTV), single-unit recordings, and evoked potentials from the olfactory of skate (Raja erinacea). J Neurophysiol 64:1767-1790.

Cinelli AR, Salzberg BM (1992) Dendritic origin of late events in optical recordings from salamander olfactory bulb. J Neurophysiol 68:786-806.

Collingridge GL, Bliss TVP (1985) NMDA receptors-their role in long-term potentiation. Trends Neurosci 10:288-293.

Dittman JS, Regehr WG (1996) Contributions of calcium-dependent and calcium-independent mechanisms to presynaptic inhibition at a cerebellar synapse. J Neurosci 16:1623-1633.

Emri Z, Turner JP, Crunelli V (1996) Tonic activation of presynaptic $\mathrm{GABA}_{\mathrm{B}}$ receptors on thalamic sensory afferents. Neuroscience 72:689-698.

Ennis M, Zimmer LA, Shipley MT (1996) Olfactory nerve stimulation activates rat mitral cells via NMDA and non-NMDA receptors in vitro. NeuroReport 7:989-992.

Faber DS, Korn H (1988) Synergism at central synapses due to lateral diffusion of transmitter. Proc Natl Acad Sci USA 85:8708-8712.

Freeman WJ (1972a) Spatial divergence and temporal dispersion in primary olfactory nerve of the cat. J Neurophysiol 35:733-744.

Freeman WJ (1972b) Depth recording of averaged evoked potential of olfactory bulb. J Neurophysiol 35:780-796.

Freeman WJ (1974a) Relation of glomerular neuronal activity to glomerular transmission attenuation. Brain Res 65:77-90.

Freeman WJ (1974b) Attenuation of transmission through glomeruli of olfactory bulb on paired shock stimulation. Brain Res 65:91-107.

Getchell TV, Shepherd GM (1975) Short-axon cells in the olfactory bulb: dendrodendritic synaptic interactions. J Physiol (Lond) 251:523-548.

Grinvald A, Manker A, Segal M (1982) Visualization of the spread of electrical activity in rat hippocampal slices by voltage-sensitive optical probes. J Physiol (Lond) 333:269-291.

Grinvald A, Frostig RD, Lieke E, Hildesheim R (1988) Optical imaging of neuronal activity. Physiol Rev 68:1285-1366.

Hálasz N, Greer CA (1993) Terminal arborizations of olfactory nerve fibers in the glomeruli of the olfactory bulb. J Comp Neurol 337:307-316.

Heyward PM, Ennis M, Shipley MT (1996) Biophysical properties of rat olfactory bulb neurons: nystatin-perforated whole cell recordings in an in vitro slice preparation. Soc Neurosci Abstr 22:2018.

Isaacson JS, Solís JM, Nicoll RA (1993) Local and diffuse synaptic actions of GABA in the hippocampus. Neuron 10:165-175.

Jahr CE, Nicoll RA (1981) Primary afferent depolarization in the in vitro frog olfactory bulb. J Physiol (Lond) 318:375-384.

Kauer JS, Senseman DM, Cohen LB (1987) Odor-elicited activity monitored simultaneously from 124 regions of the salamander olfactory bulb using a voltage-sensitive dye. Brain Res 418:255-261.

Kombian SB, Zidichouski JA, Pittman QJ (1996) GABA $_{B}$ receptors presynaptically modulate excitatory synaptic transmission in the rat supraoptic nucleus in vitro. J Neurophysiol 76:1166-1179.

Konnerth A, Obaid AL, Salzberg DM (1987) Optical recording of electrical activity from parallel fibers and other cell types in skate cerebellar slices in vitro. J Physiol (Lond) 393:681-702.

Kosaka K, Aika Y, Toida K, Heizmann CW, Hunziker W, Jacobowitz DM, Nagatsu I, Streit P, Visser TJ, Kosaka T (1995) Chemically defined neuron groups and their subpopulations in the glomerular layer of the rat main olfactory bulb. Neurosci Res 23:73-88.

Kosaka K, Toida K, Margolis FL, Kosaka T (1997) Chemically defined neuron groups and their subpopulations in the glomerular layer of the rat main olfactory bulb. II. Prominent differences in the intraglomerular dendritic arborization and their relationship to olfactory nerve terminals. Neuroscience 76:775-786.

Macrides F, Davis BJ (1983) The olfactory bulb. In: Chemical neuroanatomy (Emson PC, ed), pp 391-426. New York: Raven.

Misgeld U, Bijak M, Jarolimek W (1995) A physiological role for $\mathrm{GABA}_{\mathrm{B}}$ receptors and the effects of baclofen in the mammalian central nervous system. Prog Neurobiol 46:423-462.

Mori K (1987) Membrane and synaptic properties of identified neurons in the olfactory bulb. Prog Neurobiol 29:275-320.

Mugnaini E, Oertel WH, Wouterlood FF (1984) Immunocytochemical localization of GABA neurons and dopamine neurons in the rat main and accessory olfactory bulb. Neurosci Lett 47:221-226.

Nickell WT, Shipley MT (1992) Neurophysiology of the olfactory bulb. In: Science of olfaction (Serby MJ, Chobor KL, eds), pp 172-213. New York: Springer.

Nickell WT, Norman AB, Wyatt LM, Shipley MT (1991) Olfactory bulb dopamine receptors may be located on terminals of the olfactory nerve. NeuroReport 2:9-12. 
Nickell WT, Behbehani MM, Shipley MT (1994) Evidence for GABA B $^{-}$ mediated inhibition of transmission from the olfactory nerve to mitral cells in the rat olfactory bulb. Brain Res Bull 35:119-123.

Nickell WT, Shipley MT, Behbehani MM (1996) Orthodromic synaptic activation of rat olfactory bulb mitral cells in isolated slices. Brain Res Bull 39:57-62.

Nicoll RA (1971) Pharmacological evidence for GABA as the transmitter in granule cell inhibition in the olfactory bulb. Brain Res 35:137-149.

Nicoll RA (1972) Olfactory nerves and their excitatory action in the olfactory bulb. Exp Brain Res 14:185-197.

Olpe H-R, Steinmann MW, Greiner K, Pozza MF (1994) Contribution of presynaptic GABA-B receptors to paired-pulse depression of GABA-responses in the hippocampus. Naunyn Schmiedebergs Arch Pharmacol 349:473-477.

Orbach HS, Cohen LB (1983) Optical monitoring of activity from many areas of the in vitro and in vivo salamander olfactory bulb: a new method for studying functional organization in the vertebrate central nervous system. J Neurosci 3:2251-2262.

Pinching AJ, Powell TPS (1971) The neuropil of the glomeruli of the olfactory bulb. J Cell Sci 9:347-377.

Potapov AA (1985) Baclofen inhibition of synaptic transmission in frog olfactory bulb glomeruli. Neirofiziologiia 17:834-837.

Price JL, Powell TPS (1970) The synaptology of granule cells of the olfactory bulb. J Cell Sci 7:125-155.

Rall W, Shepherd GM (1968) Theoretical reconstruction of field potentials and dendrodendritic synaptic interactions in olfactory bulb. J Neurophysiol 31:884-915.

Reese TS, Brightman MW (1970) Olfactory surface and central olfactory connections in some vertebrates. In: Taste and smell in vertebrates (Wolstenholme GEW, Knight J, eds), pp 115-149. London: CIBA Foundation.

Reese TS, Shepherd GM (1972) Dendro-dendritic synapses in the central nervous system. In: Structure and function of synapses (Pappas GD, Purpura DP, eds), pp 121-136. New York: Raven.

Salzberg BM, Davila HV, Cohen LB (1973) Optical recordings of impulses in individual neurons of an invertebrate central nervous system. Nature 246:508-509.

Salzberg BM, Grinvald A, Cohen LB, Davila HV, Ross WN (1977) Optical recordings of neuronal activity in an invertebrate central nervous system: simultaneous monitoring of several neurons. J Neurophysiol 40:1281-1291.

Salzberg BM, Obaid AL, Gainer H (1985) Large and rapid changes in light scattering accompany secretion by nerve terminals in the mammalian neurohypophysis. J Gen Physiol 86:395-411.

Senseman DM (1996) High-speed optical imaging of afferent flow through rat olfactory bulb slices: voltage-sensitive dye signals reveal periglomerular cell activity. J Neurosci 16:313-324.

Shepherd GM (1990) Olfactory bulb. In: The synaptic organization of the brain (Shepherd GM, ed), pp 133-169. New York: Oxford University Press.

Shepherd GM (1991) Computational structure of the olfactory system. In: Olfaction (Davis JL, Eichenbaum H, eds), pp 3-41. Cambridge: MIT.

Shipley MT, Ennis M (1996) Functional organization of olfactory system. J Neurobiol 30:123-176.

Shipley MT, McLean JH, Zimmer LA, Ennis M (1996) The olfactory system. In: Handbook of chemical neuroanatomy, Vol 12, Integrated systems of the CNS, Pt III (Björklund A, Hökfelt T, Swanson LW, eds), pp 467-571. Amsterdam: Elsevier.

Shipley MT, Heyward PM, Anderjaska VA, Solodkin A (1997) Electrophysiological characterization of rat main olfactory bulb (MOB) glomerular layer (GL) cell populations. Int Symposium Olfaction and Taste and AChemS XIX 23:30.

Stone EA, Sessler FM, Weimin L (1990) Glial localization of adenylatecyclase-coupled $\beta$-adrenoreceptors in rat forebrain slices. Brain Res 530:295-300.

Thompson SM, Capogna M, Scanziani M (1993) Presynaptic inhibition in the hippocampus. Trends Neurosci 16:222-227.

Wellis DP, Scott JW (1990) Intracellular response of identified rat olfactory bulb interneurons to electrical and odor stimulation. J Neurophysiol 64:932-947.

White EL (1972) Synaptic organization in the olfactory glomerulus of the mouse. Brain Res 37:69-80.

Wu J-Y, Cohen LB (1993) Fast multisite optical measurement of membrane potential. In: Fluorescent and luminescent probes for biological activity (Mason WT, ed), pp 389-404. London: Academic

Yagodin S, Aroniadou-Anderjaska V, Zimmer LA, Ennis M, Shipley MT, Keller A (1996) Functional organization and pharmacology of rat olfactory bulb revealed by optical imaging. Soc Neurosci Abstr 22:259.

Yokoi M, Mori K, Nakanishi S (1995) Refinement of odor molecule tuning by dendrodendritic synaptic inhibition in the olfactory bulb. Proc Natl Acad Sci USA 92:3371-3375.

Zimmer LA, Phillips S, Ennis M, Shipley MT (1995) Dopamine $\left(\mathrm{D}_{2}\right)$ receptor activation blocks sensory evoked excitation of rat mitral cells in vitro. Soc Neurosci Abstr 21:1514. 